\title{
In Other Words:
}

\section{What's Happened to Metaphors in the Translation of Political Texts}

Yiqing Liu, China Foreign Languages Publishing Administration, China

Caiwen Wang, School of Humanities, University of Westminster, UK

\begin{abstract}
This empirical study takes a cognitive perspective and examines the translation of metaphors in speeches by Chinese President Xi Jinping as collected in the first volume of the book The Governance of China published in 2014. The study draws upon Lakoff and Johnson's conceptual metaphor theory and Newmark's categories of translation procedure for metaphors. The researchers' data analysis has shown that (1) four out of the eight existing translation procedures for metaphors are employed in translating Xi's metaphors, and (2) while the use of one translation procedure reflects similar cognitive mapping conditions between the source and the target culture, the use of the other procedures does not always correlate with the similarities or differences in cognitive mappings between the two cultures in question. The research raises new inquiries regarding metaphor translation, and the researchers accordingly discuss the implications of their findings for metaphor translation pedagogy and future translation studies.
\end{abstract}

\section{KEYWORDS}

Cognitive Approach, Conceptual Metaphor, Conceptual Metaphor Theory (CMT), Political Text, Rhetorical Effect, Sense, Translation Procedure

\section{INTRODUCTION}

In Translation Studies, metaphors are often treated as a translatability issue (e.g., Schäffner, 2004). From a cognitive point of view, metaphors reflect the way of thinking or conceptualising of an author (speaker or writer) representing a culture (Lakoff \& Johnson, 1980). It follows that the translatability issue of metaphors has to do with whether or not the concepts employed in them will be recognised for both their senses and effects in a target culture if translated literally. Where metaphors are not translated literally, it is worth investigating whether or not the adopted translation procedures have a bearing on the differences in conceptualising between a source and a target culture, and consequently whether or not these procedures reflect the compromise between translating the sense and appealing to the effect of metaphors.

The current study departs from Lakoff and Johnson's (1980) Conceptual Metaphor Theory (CMT) and draws upon Newmark's (1980) categories of translation procedure for metaphors in its attempt to 
examine how the metaphors in Chinese President Xi Jinping's speeches are translated into English. It seeks to answer four research questions as below:

RQ1: What kinds of conceptual metaphor are used by President Xi in his speeches and what are their frequencies of occurrence?

RQ2: What translation procedures are employed for the metaphors in President Xi's speeches?

RQ3: What cognitive domains are reflected in the translation procedures identified in RQ2?

RQ4: Do the translation procedures identified in RQ2 associate with cultural similarities or differences in cognitive domains between English and Chinese?

\section{THEORETICAL FRAMEWORK}

\section{Conceptual Metaphor and the Cognitive Approach}

Conceptual metaphor means 'metaphorical concept' where ' $\mathrm{t}]$ he essence' is 'understanding and experiencing one kind of thing in terms of another' (Lakoff \& Johnson, 1980, pp.5-6). This conceptualisation highlights the cognitive side of metaphors and distinguishes itself from definitions given from a pure linguistic viewpoint, such as that in Oxford English Dictionary (2020) where the rhetorical device is defined as '[a] figure of speech in which a name or descriptive word or phrase is transferred to an object or action different from, but analogous to, that to which it is literally applicable', and that in Aristotle's rhetoric where metaphor refers to 'the application of an alien name by transference' (Aristotle's Rhetoric, 2010).

The current study believes this cognitive perspective relates well to the translatability issue surrounding metaphors (Schäffner, 2004), because the consideration of whether or not a metaphor is translatable has a bearing on whether or not the 'understanding and experiencing of one kind of thing in terms of another' is shared between a source and a target culture represented by the two languages in question. This cognitive perspective also makes it possible to categorise metaphorical expressions in a systematic way for the study of their translations. For instance, the following metaphorical expressions are all underpinned by the conceptual metaphor ARGUMENT IS WAR ${ }^{1}$ and it would be worthwhile to group them together so as to examine if they are translated in a similarly systematic way:

\section{Your claims are indefensible.}

He attacked every weak point in my argument.

I've never won an argument with him.

(Lakoff \& Johnson, 1980, p.4)

The cognitive stance for metaphors is shared by more recent scholars. For example, Gibbs (2008, p.3) recognises metaphors as 'a fundamental scheme by which people conceptuali[s]e the world and their activities', and Gibbs (2017, p.3) states that metaphors may be used to reach specific communicative goals, which includes explaining ideas that are otherwise difficult to convey, making expressions more concise, and impressively capturing our vivid experience. Additionally, CharterisBlack (2005) points out that metaphors do not just have linguistic and pragmatic/cultural characteristics, but also possess cognitive characteristics:

The cognitive characteristic is that a metaphor is caused by, and may cause, a shift in the conceptual system. The basis for the conceptual shift is the relevance or psychological association between the attributes of the original referent of a metaphor (i.e., of a word in its source domain) and those of the metaphor target. This relevance or association is usually based on some previously unperceived similarity between source and target and is often determined by the values placed on them by cultures (p.15). 
Applying these cognitive understandings of metaphors to the study of metaphor translation, the authors of the current paper take the view that since cognitive experiences of people vary from culture to culture, the translation procedures for metaphors may be varied. The current study seeks to find out if there exists a relationship between a chosen translation procedure and the underlying cultural-cognitive mappings of a metaphor.

Conceptual metaphors have three sub-categories: structural metaphors, orientational metaphors and ontological metaphors (Lakoff \& Johnson, ibid.). Structural metaphors refer to situations where 'one concept is metaphorically structured in terms of another' (Lakoff \& Johnson, ibid., p.14), such as the ARGUMENT IS WAR metaphor. In orientational metaphors, a system of concepts is organised with respect to one another, often in terms of spatial orientation. Examples include the HAPPY IS UP; SAD IS DOWN metaphors. Ontological metaphors refer to cases where activities, events, ideas, etc. are viewed as concrete entities or substances. A typical subtype of ontological metaphors is the personification of non-human entities which allows us to understand the latter in human terms (Lakoff \& Johnson, ibid., pp.33-34), such as A NATION IS A PERSON.

The current research seeks to uncover the conceptual mappings in a SL metaphor and examine how they are dealt with in translation.

\section{Political Texts and Metaphors}

Texts can be considered political when they are produced by a politician and/or they contain some form of power struggle (Chilton \& Schäffner, 1997, p.212; Gagnon, 2010, p.252). As metaphor is one of the means for rhetorical effects and for persuasive power, it is no wonder that metaphors are used by politicians, especially experienced politicians, in their speeches to excite and inspire (CharterisBlack, $2005 \& 2014$ ). Whilst the senses and rhetorical effects of metaphors may be recognised by an audience sharing the speaker's linguistic and cultural background, it is equally important to examine how metaphors in political texts are translated and whether or not such translation will resonate with the target audience.

Charteris-Black (2005) has built several corpora of conceptual metaphors in English political speeches respectively by Martin Luther King, Margaret Thatcher, Bill Clinton, Tony Blair and George W. Bush. These corpora are useful for investigating to what extent the English way of thinking or conceptualising is different from that of other cultures and thus help assess translations from other languages into English. In the current study, these corpora are drawn upon in the discussions of English translations of conceptual metaphors in President Xi's speeches.

According to Zhu and Zeng (2013), Huang (2014) and Weng (2017), studies on Chinese to English translation of conceptual metaphors in political texts are few and far between. The current study hopes to fill this gap.

President Xi Jinping's works abound with metaphorical language, as widely reported in the media. For example, when addressing the first session of the Thirteenth National People's Congress of China on 20 March 2018, Xi made an appeal regarding the Chinese dream towards the end of his speech with a number of metaphors:

我们要 $[i]$ 乘着新时代的 $[i i]$ 浩荡东风, $[\mathrm{iii}]$ 加满油, $[\mathrm{iv}]$ 把稳舵, 鼓足劲, 让 $[\mathrm{v}]$ 承 载着13亿多中国人民伟大梦想的 [vi] 中华巨轮继续 [vii]䢃波斩浪、 [viii]扬帆远航，胜利 [ix]驶向充满希望的明天! (The literal translation of this sentence is: we shall sail with this era's strong east wind, fully fuelled, with the helm firmly held and with our utmost effort. We shall let the giant steamer of China, which carries the great dreams of over 1.3 billion Chinese people, continue to cleave through the waves for a triumphant voyage afar towards our promising future) (Xinhua News Agency, 2018; emphasis added)

The numbered expressions in the above sentence centre around the conceptual metaphor NATIONAL DEVELOPMENT IS NAVIGATION/A JOURNEY, where different aspects of national development are conceptualised in terms of different aspects of navigation. 
Similarly, the first volume of President Xi Jinping's The Governance of China (2014) is abundant with metaphorical expressions and is a good source of data for studies of how Chinese conceptual metaphors in political texts are translated.

The English translation of the book was conducted by a designated team consisting of native speakers of Chinese and English (China Daily, 2018), and the publishing project was a joint effort of the Chinese State Council Information Office, the Party Literature Research Office of the CPC Central Committee and the China International Publishing Group (Publisher's Note). This suggests that the translation, including that of metaphors, was agreed upon by the designated team instead of being individual translators' discretions. It is also reasonable to assume that the designated team worked collectively to achieve the intended goal of the book for the target readership, which is to 'respond to rising international interest and to enhance the rest of the world's understanding of the Chinese government's philosophy and its domestic and foreign policies' (Publisher's Note). Such being the case, the current study will have additional value for research into translation procedures for metaphors as the quality of the translation under examination is assumedly high.

\section{Translation Procedures}

Various translation procedures for metaphors have been proposed in literature, e.g., Nida and Reyburn (1981), van den Broeck (1981), Newmark (1980), Dobrzyńska (1995), Schäffner (2004). General procedures include translating metaphors from the Source Language (SL) into either non-metaphors or metaphors in the Target Language (TL) (Nida \& Reyburn, 1981, pp.41-42). Van den Broeck (1981, p.77) proposed three 'modes' as below, which Schäffner (2004, p.1256) viewed as 'a tentative scheme, i.e., as theoretical possibilities', or 'hypotheses about translatability':

1. Translation "sensu stricto", meaning that the metaphor in the SL is transferred literally into the $T L$ regardless of the idiomaticity of the translation

2. Substitution, referring to the cases where the metaphor in the SL is replaced by another with more or less the same meaning in the TL

3. Paraphrase, meaning that the metaphor is rendered into a non-metaphorical expression in the TL

Dobrzyńska (1995, p.599) proposed a similar model to Van den Broeck's: the $M \rightarrow M$ procedure, the $\mathrm{M}_{1} \rightarrow \mathrm{M}_{2}$ procedure and the $\mathrm{M} \rightarrow \mathrm{P}$ procedure, where $\mathrm{M}$ means 'metaphor' and $\mathrm{P}$ means 'the approximate literal paraphrase of the original metaphor'.

The current study followed Newmark's (1980) categorisation of translation procedures, as Nemark based his categorisation on his own translation practitioning experiences, and according to Shuttleworth (2014, p.58), few other significant procedures have been proposed thereafter with further modifications or additions only amounting to footnotes to Newmark's list. Newmark's procedures for translating metaphors are:

1. Reproducing the same image in the TL, provided the image has comparable frequency and currency in the appropriate register.

2. Replacing the image in the SL with a standard TL image which does not clash with the TL culture

3. Translating metaphor by a simile, retaining the image

4. Translating metaphor (or simile) by simile plus sense to address both the layman and the expert in the target reader

5. Conversion of metaphor to sense

6. Modification of metaphor

7. Deletion

8. Using the same metaphor combined with sense 
It is noteworthy that Newmark defined metaphor as 'the word(s) taken from the image' (1980, p.93). His 'image' refers to the item that is used to describe the object and corresponds to 'source domain' in CMT ('Object' is the item or topic that is described by the metaphor and corresponds to 'target domain' in CMT). 'Sense' means the aspect in which the object and image are similar.

In their study of a Chinese-English parallel corpus of political texts, Zhu and Zeng (2013, p.85) found three translation procedures for metaphors: a) retaining the source domain of the metaphor, b) replacing the source domain with a new source domain in the TT, and c) replacing the source domain with a gloss of the target domain in the TT. The researchers of the current study hope they will confirm or disconfirm these findings, and/or discover new procedures.

\section{METHODOLOGY}

\section{Data Source}

The first volume of the book The Governance of China by President Xi Jinping (published by the Foreign Language Press of China in 2014) contains seventy-nine articles, constituting Xi's major works during the period from November 2012 to June 2014. The book is an official compilation of Xi's speeches, talks, interviews, instructions and correspondence. It is organised in eighteen topic-oriented chapters, including topics such as the Chinese dream, legislation, domestic economic development, ecological progress, cultural soft power, national defence, the combat against corruption, the Communist Party of China (CPC) leadership and foreign policies.

In the current study, the researchers randomly selected fourteen articles from the book. According to Shadish et al. (2002) and Moore et al. (2011), random sampling ensures that results obtained approximate what would have been obtained if the entire data set had been measured. The selected texts take up $78 \%$ the eighteen topics in the volume and 24\% (100 pages) of the 420-page body text.

\section{Data Coding}

The researchers identified conceptual metaphors in the Source Text (ST) by applying CharterisBlack's source domain approach (2014). This is 'grouping together "linguistic" metaphors on the basis of their source domains - the semantic field of the words in them (for example, journey, war or sports) to generate a "conceptual" metaphor - one that connects these words with a metaphor target to which they typically refer' (ibid., p.187). Next, the corresponding translations of these metaphorical expressions in the Target Text (TT) were identified and the underpinning translation procedures examined by following Newmark's categorisation.

\section{Data}

According to Lakoff and Johnson (1980, p.ix), a prominent feature of conceptual metaphors is their systematicity. That is, metaphors describe one concept in terms of another systematically. For instance, in the conceptual metaphor ARGUMENT IS WAR, expressions from war vocabulary such as 'indefensible', 'attack', 'win' and 'target' are used systematically to discuss aspects of an argument. Because of this systematicity characteristic, Charteris-Black (2014, p.193) states that conceptual metaphors should only be identified when the same source and target domains are systematically used in a discourse. The current study followed this approach, thereafter, focused on conceptual metaphors that have multiple derivative expressions and/or occurrences, and excluded metaphorical expressions that only appear once.

In total, the researchers manually identified fifty-eight recurrent metaphorical expressions and their English translations. The sample covers all three types of conceptual metaphors and their translations. The data is presented in Table 1. 
Table 1. Data overview

\begin{tabular}{|l|c|c|c|c|}
\hline \multirow{2}{*}{\multicolumn{2}{|c}{ Translation Procedure }} & \multicolumn{3}{c|}{ Type of Metaphor } \\
\cline { 2 - 5 } & $\begin{array}{c}\text { Structural } \\
\text { Metaphor }\end{array}$ & $\begin{array}{c}\text { Ontological } \\
\text { Metaphor }\end{array}$ & $\begin{array}{c}\text { Orientational } \\
\text { Metaphor }\end{array}$ & Subtotal \\
\hline (a) Reproducing the same image in the TL & 19 & 11 & 6 & 36 \\
\hline $\begin{array}{l}\text { (b) Replacing the image in the SL with a standard } \\
\text { TL image }\end{array}$ & 5 & 1 & 2 & 8 \\
\hline (c) Converting the metaphor to sense & 8 & 1 & 2 & 11 \\
\hline (d) Using the same metaphor combined with sense & 2 & 1 & $/$ & 3 \\
\hline Subtotal & 34 & 14 & 10 & Total: 58 \\
\hline
\end{tabular}

\section{DATA ANALYSIS AND RESULTS}

As can be seen from Table 1, among all the metaphorical expressions, structural metaphors constitute the majority, accounting for $58.62 \%(=34 / 58)$ of the total, followed by ontological metaphors and orientational metaphors, accounting for $24.14 \%(=14 / 58)$ and $17.24 \%(=10 / 58)$ respectively.

Four translation procedures from Newmark's list are identified in the sample. These are: (a) reproducing the same image as in the ST, (b) replacing the image in the ST with a standard TL image which does not clash with the TL culture, (c) converting the metaphor to sense, and (d) using the same metaphor combined with sense. The procedure of reproducing the same image, the most preferred procedure by Newmark, is the most commonly used in the sample across all three categories of conceptual metaphor. As the analysis below will reveal, this finding indicates that a lot of Chinese conceptual metaphors have similar cognitive mapping conditions to English ones. The second most common procedure is the conversion of the metaphor to sense, suggesting that some Chinese conceptual metaphors might be untranslatable due to their different cognitive mapping conditions. Detailed analysis of the data in the following, however, will show that this is not always the case. The third most common procedure, i.e., Replacing the image in the SL with a standard TL image, uncovers a different and at times puzzling picture. The least used procedure in the sample is the combination of the original metaphor and sense.

Since structural metaphors and ontological metaphors occurred at a significantly higher frequency than orientational metaphors, respectively $58.62 \%(=34 / 58)$ and $24.14 \%(=14 / 58)$, the translation procedures for them will be the focus for analysis and discussion in the current paper.

While analysing, the researchers will provide a literal rendering of a metaphor in question where necessary, with minimal grammar adjustment of the original metaphorical expression, so as to assess the relevant translation procedure in the official translation.

\section{Reproducing the Same Image in the TL}

As can be seen from Table 1, most structural metaphors $(19 / 34=55.88 \%)$ and most ontological metaphors $(11 / 14=78.57 \%)$ are translated through this procedure.

\section{Structural Metaphors}

In essence, the translation procedure 'reproducing the same image in the TL' literally translates an SL metaphor. Example [1] illustrates the Chinese conceptual metaphor NATIONAL DEVELOPMENT IS A JOURNEY. The image of journey occurs highly frequently in English political discourse. According to Chilton (2006, p.64), the source-path-goal schema is one of the important sources of the Western political concepts. The conceptual metaphor LONG-TERM PURPOSEFUL ACTIVITIES ARE JOURNEYS is commonly used in speeches by influential Western politicians from different 
times, such as Winston Churchill, Martin Luther King, Margaret Thatcher, Bill Clinton and Tony Blair (Charteris-Black, 2005, p.45 \& 152). As such, the reproduction of the image as in Example [1] reflects similar conceptualisation between the SL and the TL.

Table 2. Example [1]

\begin{tabular}{|l|l|l|}
\hline \multicolumn{1}{|c|}{ ST } & \multicolumn{1}{|c|}{ TT } \\
\hline & $\begin{array}{l}\text { 全国各族人民......战胜前进道路上的各种艰 } \\
\text { 难险阻 }\end{array}$ & $\begin{array}{l}\text { The Chinese people of all ethnic groups have [...] } \\
\text { surmounted all difficulties and obstacles on our way ahead. }\end{array}$ \\
\hline
\end{tabular}

\section{Ontological Metaphors}

The example here for ontological metaphors manifests a similar picture to that of structural metaphors as in Example [1]. The Constitution, an abstract idea, is personified via the conceptual metaphor CONSTITUTION IS A PERSON. Just like in Chinese, personification in English has the power to persuade the reader because it evokes 'our attitudes, feelings and beliefs about people and applies them to our attitudes, feelings and beliefs about abstract political entities' (Charteris-Black, 2005, p.41). Both Churchill and Blair used personification to conceptualise the abstract struggle between good and evil to promote their own political ideals while attacking their political adversaries in times of conflict: Churchill mainly used personification to highlight concepts with positive evaluation (e.g., freedom and British empire) while Blair focused more on concepts with negative evaluation such as terrorism (ibid., p.162-63). In Example [2], President Xi relates personification with positive evaluation like Churchill. The literal translation of the metaphor in question therefore resonates with the TL audience.

Table 3. Example [2]

\begin{tabular}{|l|l|l|}
\hline \multicolumn{1}{|c|}{ ST } & \multicolumn{1}{|c|}{ TT } \\
\hline & $\begin{array}{l}\text { 宪法的生命在于实施,宪法的权威也在 } \\
\text { 于实施。 }\end{array}$ & $\begin{array}{l}\text { The life of the Constitution is in its implementation, and so is its } \\
\text { authority. }\end{array}$ \\
\hline
\end{tabular}

The researchers' examination of all cases of the metaphors translated by this procedure shows that the translation procedure reflects the similarities in cognitive mappings between English and Chinese in similar political texts.

\section{Converting Metaphor to Sense}

This is the second most used translation procedure for structural metaphors $(8 / 34=52.94 \%)$ and ontological metaphors $(1 / 14=7.14 \%)$.

\section{Structural Metaphors}

Example [3] illustrates the metaphor NATIONAL DEVELOPMENT IS A JOURNEY in the SL. The image of 旗帜 (banner) in Chinese is considerably common, especially in political discourse, and is used figuratively to refer to a thinking, theory, doctrine or political power, or a model to be followed in a particular field (Modern Chinese Dictionary, 2016). In English, the word 'banner' has a similar figurative meaning, which is 'anything displayed as a profession of principles' (Oxford English Dictionary, 2020). If people do something under the banner of a particular cause, idea, or belief, it 
means they support that cause, idea, or belief (Collins COBUILD Dictionary, 2006). Consequently, one would expect the metaphor in [3] to be translated literally. However, as is clear, this is not the case.

\section{Table 4. Example [3]}

\begin{tabular}{|l|l|l|l|}
\hline \multicolumn{1}{|c|}{ ST } & \multicolumn{1}{|c|}{ Literal translation } & \multicolumn{1}{c|}{ TT } \\
\hline & $\begin{array}{l}\text { 我们将高举和平、发展、 } \\
\text { 合作、共赢的旗帜。 }\end{array}$ & $\begin{array}{l}\text { We will hold high the banner of } \\
\text { peace, development, cooperation and } \\
\text { mutual benefit. }\end{array}$ & $\begin{array}{l}\text { We will uphold the principle of peace, } \\
\text { development, cooperation and mutual } \\
\text { benefit. }\end{array}$ \\
\hline
\end{tabular}

Among the eight structural metaphors translated through this procedure, five, including the above one, have removed the SL image which is also commonly used in the TL for conceptualising. For the other three, two cases fit the situation where Newmark would typically recommend converting the metaphor to sense. The typical situation is where 'this procedure is common and is to be preferred to any replacement of an SL by a TL image which is too wide off the sense or the register (including ... current frequency as well as the degrees of formality, emotional tone, generality etc.)' depending on the type of text (1980, p.97). One of the two cases is presented below (the underlying conceptual metaphor is NATIONAL DEVELOPMENT IS A JOURNEY).

\section{Table 5. Example [4]}

\begin{tabular}{|c|c|l|l|}
\hline ST & \multicolumn{1}{|c|}{ Literal translation } & \multicolumn{1}{c|}{ TT } \\
\hline & & $\begin{array}{l}\text { "A thing is yet to be done until it is } \\
\text { done”, as an old saying goes. } \\
\text { [Endnote] }{ }^{6} \text { Strategies of the States } \\
\text { Thavelling 90 of a 100-mile journey is } \\
\text { the same as travelling half of it. } \\
\text { (Zhan Guo Ce), a collection of stories } \\
\text { of political strategists of the Warring } \\
\text { States Period (475-221 BC). }\end{array}$ \\
\hline
\end{tabular}

The third of the three cases, or the one case different from all of the rest is presented below.

Table 6. Example [5]

\begin{tabular}{|l|l|l|l|}
\hline \multicolumn{1}{|c|}{ ST } & \multicolumn{1}{|c|}{ Literal translation } & \multicolumn{1}{c|}{ TT } \\
\hline & $\begin{array}{l}\text { 没有理想信念,或理想信念不 } \\
\text { 坚定,精神上就会“缺钻”,就会 } \\
\text { 得“软骨病”。 }\end{array}$ & $\begin{array}{l}\text { an absence of ideals and convictions } \\
\text { or wavering in our ideals and } \\
\text { convictions will lead to 'calcium } \\
\text { deficiency', thereafter 'rickets'. }\end{array}$ & $\begin{array}{l}\text { an absence of ideals and convictions } \\
\text { or wavering in our ideals and } \\
\text { convictions will lead to fatal moral } \\
\text { weakness. }\end{array}$ \\
\hline
\end{tabular}

Here, 缺钻 and 软骨病are rendered as 'moral weakness'. The SL metaphor, THE MIND IS A BODY, is thus converted to its sense in the translation. This example is closely related to Example [8], which comes later in the current paper but occurs earlier in the source book and where the translation procedure is replacement with a new image in the same conceptual metaphor. It is not clear why here the translation procedure is not the same as that from Example [8], as one would expect consistency to be observed. 


\section{Ontological Metaphors}

This is the only case found for the procedure 'converting metaphor to sense' in translating ontological metaphors. Behind the metaphor CHINA IS A PERSON, the speaker compares the quintessence of traditional Chinese culture to a person's genes or DNA. This scientific metaphor is omitted in the TT and only the sense is conveyed instead. While the DNA metaphor is not uncommon in English, it is not clear why the original metaphor is reduced to its sense in translation.

Table 7. Example [6]

\begin{tabular}{|c|l|l|l|}
\hline \multicolumn{1}{|c|}{ ST } & \multicolumn{1}{c|}{ Literal translation } & \multicolumn{1}{c|}{ TT } \\
\hline & $\begin{array}{l}\text { 中华优秀传统文化已经 } \\
\text { 成为中华民族的基因。 }\end{array}$ & $\begin{array}{l}\text { The brilliant traditional Chinese } \\
\text { culture is the DNA (or genes) of the } \\
\text { nation }\end{array}$ & $\begin{array}{l}\text { The brilliant traditional Chinese culture is } \\
\text { the essence of the nation }\end{array}$ \\
\hline
\end{tabular}

\section{Replacing the Image in the SL With a Standard TL Image}

As Table 8 shows, five out of thirty-four structural metaphors are translated via this procedure, constituting $14.71 \%$, and one of eleven ontological metaphors is translated this way, constituting $7.14 \%$.

\section{Structural Metaphors}

In [7], the Chinese phrases 起点 (starting point) and 终点 (ending point) normally conjure up an image of a finite distance which fits the broad metaphor NATIONAL DEVELOPMENT IS A JOURNEY. However, this image in the ST is replaced with the image of race in the TT. In line with the new image, the phrase 终点 is translated as 'finishing line' which refers to 'the place on the track or course where the race officially ends' (Collins COBUILD Dictionary, 2006).

Table 8. Example [7]

\begin{tabular}{|l|l|l|l|}
\hline \multicolumn{1}{|c|}{ ST } & \multicolumn{1}{|c|}{ Literal translation } & \multicolumn{1}{c|}{ TT } \\
\hline & $\begin{array}{l}\text { 亚洲和世界和平发展、 } \\
\text { 合作共赢的事业没有终 } \\
\begin{array}{l}\text { 点,只有一个接一个的 } \\
\text { 新起点。 }\end{array}\end{array}$ & $\begin{array}{l}\text { The cause of the peaceful development } \\
\text { and mutually beneficial cooperation } \\
\text { in Asian and the world has no } \text { ending } \\
\text { point. It only has one starting point } \text { after } \\
\text { another. }\end{array}$ & $\begin{array}{l}\text { To enhance peaceful development and } \\
\text { mutually beneficial cooperation in } \\
\text { Asia and the world is } a \text { race that has } \\
\text { one starting point after another and } \\
\text { knows no finishing line. }\end{array}$ \\
\hline
\end{tabular}

While achieving the rhetorical effect of a metaphor, the replacement has introduced new components into the TT. Compared with the original image, the image of a race highlights the element of competition. As competitors in a race usually try to outperform one another to be the first to reach the finishing line, the translation procedure used here raises the question of whether or not they introduced unnecessary components of competition and rivalry, which may be inappropriate given the political context.

Among the five structural metaphors translated through this procedure, two, including the above one, have imported new senses. The other three share a different feature, which is that the replaced image does not introduce extra senses. Moreover, the new image used in the translation falls in the same conceptual metaphor, as illustrated below. 
Table 9. Example [8]

\begin{tabular}{|l|l|l|l|}
\hline \multicolumn{1}{|c|}{ ST } & \multicolumn{1}{c|}{ Literal translation } & \multicolumn{1}{c|}{ TT } \\
\hline & $\begin{array}{l}\text { 我常说,理想信念是共产党 } \\
\text { 人精神上的“钻”。 }\end{array}$ & $\begin{array}{l}\text { I have often said that ideals and } \\
\text { convictions are the moral “calcium” } \\
\text { of Communists. }\end{array}$ & $\begin{array}{l}\text { I have often said that ideals and } \\
\text { convictions are the moral “marrow” } \\
\text { of Communists. }\end{array}$ \\
\hline
\end{tabular}

As can be seen, both the ST and the TT are underpinned by the metaphor THE MIND IS A BODY. However, the ST uses 'calcium' to conceptualise 'ideals and convictions' and the TT by contrast uses 'marrow'. Both 'calcium' and 'marrow' convey the sense of the metaphor and at the same achieve the effect. Different images as they are, they fall in the same source domain for 'body'.

\section{Ontological Metaphors}

This is the only case for ontological metaphors that employs the procedure 'replacing the image with a standard TL image' (This example was counted twice in the sample for metaphors, as it contains two conceptual metaphors, namely, RELAITIONS BETWEEN NATIONS ARE TREES and RELAITIONS BETWEEN NATIONS ARE A PERSON. The focus here is the personification metaphor). Like 'calcium' and 'marrow' in Example [8], both 'bloodline' and 'lifeline' in Example [9] convey the sense of the conceptual metaphor. On the surface, the image of the metaphor is replaced. However, from a cognitive point of view, 'bloodline' and 'lifeline' fall into the same source domain for the life of a person. In this sense, the conceptual metaphor involved, as in [8] and [9], are identical in ST and TT at the macro level, and thus the translation procedure used here essentially retains the ST conceptual metaphor. Consequently, the translation procedure involved could arguably be categorised as 'reproducing the same image in the TL', and it reflects the systematicity feature of conceptual metaphors, too. The significance of this finding will be discussed later along with others.

Table 10. Example [9]

\begin{tabular}{|l|l|l|l|}
\hline \multicolumn{1}{|c|}{ ST } & \multicolumn{1}{|c|}{ Literal Translation } & \multicolumn{1}{c|}{ TT } \\
\hline & $\begin{array}{l}\text { 中非关系的根基和血脉在 } \\
\text { 人民。 }\end{array}$ & $\begin{array}{l}\text { The roots and bloodline of } \\
\text { China-Africa relations are } \\
\text { people. }\end{array}$ & $\begin{array}{l}\text { The roots and lifeline of China-Africa } \\
\text { relations are our people. }\end{array}$ \\
\hline
\end{tabular}

\section{Using the Same Metaphor Combined With Sense}

This is the least used translation procedure. The percentage of its use for structural metaphors and ontological metaphors is respectively $5.88 \%(=2 / 34)$ and $7.14 \%(=1 / 14)$.

\section{Structural Metaphors}

Here, the underlying conceptual metaphor is RELATIONS BETWEEN NATIONS ARE TREES, which is expressed explicitly by the expression 友谊之树 ('the tree of [...] friendship'). In the translation, whereas the image of tree is retained, the related element 'soil' was rendered explicitly by adding 'social support'. 
Table 11. Example [10]

\begin{tabular}{|l|l|l|l|}
\hline \multicolumn{1}{|c|}{ ST } & \multicolumn{1}{|c|}{ Literal translation } & \multicolumn{1}{c|}{ TT } \\
\hline & $\begin{array}{l}\text { 保持中国-东盟友谊之树常青, } \\
\text { 必须夯实双方关系的社会土 } \\
\text { 壤。 }\end{array}$ & $\begin{array}{l}\text { To keep the tree of China- } \\
\text { ASEAN friendship evergreen, } \\
\text { we must solidify the soil of } \\
\text { society of our relation. }\end{array}$ & $\begin{array}{l}\text { To ensure that the tree of China- } \\
\text { ASEAN friendship remains evergreen, } \\
\text { the soil of the social support for our } \\
\text { relations should be fertile. }\end{array}$ \\
\hline
\end{tabular}

\section{Ontological Metaphors}

This case illustrates depersonification, which is an extreme type of ontological metaphor. As the term suggests, depersonification refers to the 'removal of human qualities [...] from what counts as human' (Twardzisz, 2013, p.114), and is also employed by English-speaking politicians as a powerful tool to serve the delegitimisation purpose of political texts (Charteris-Black, 2005, p.182). For example, George W. Bush conceptualised terrorists as dangerous animals and parasites that need to be eliminated (Charteris-Black ibid., pp.181-82).

Table 12. Example [11]

\begin{tabular}{|c|c|}
\hline ST & TT \\
\hline $\begin{array}{l}\text { 要坚持“老虎”、“苍蝇”一起打,既 } \\
\text { 坚决查处领导干部违纪违法案件, } \\
\text { 又切实解决发生在群众身边的不 } \\
\text { 正之风和腐败问题。 }\end{array}$ & $\begin{array}{l}\text { We should continue to catch "tigers" as well as "flies"* when dealing } \\
\text { with cases of leading officials in violation of Party discipline and state } \\
\text { laws as well as misconduct and corruption problems that directly affect } \\
\text { the people's livelihood. } \\
\text { *[Footnote] Referring to high-ranking offenders as well as petty ones. - Tr. }\end{array}$ \\
\hline
\end{tabular}

In [11], the images of tigers and flies are reproduced in the TT with quotation marks and an additional explanatory footnote. As is clarified in the added footnote, the objects of the metaphor are the high-ranking and low-ranking corruption offenders. The mappings in these two metaphors are respectively HIGH-RANKING CORRUPTION OFFENDERS ARE TIGERS and LOW-RANKING CORRUPTION OFFENDERS ARE FLIES. The broader conceptual metaphor can be generalised as CORRUPTION OFFENDERS ARE BEASTS/PESTS.

While the image of flies as pests probably evokes similar feeling of disgust in both the ST and TT reader, the image of tigers might be more nuanced because it has dual cultural meanings in both the SL and the TL culture. In Chinese history and literature, the tiger is depicted both as a powerful animal worth worshiping and a terrifying predator to be controlled and killed (Jing-Schmidt \& Peng, 2017, pp.15-16). In the anti-corruption discourse of the ST, the image of tigers evokes the ST reader's anger at the corrupted power and hope for the anti-corruption efforts representing the tiger-slaying heroism (ibid., p.16). In English, a tiger can refer to 'a person of fierce, cruel, rapacious, or bloodthirsty disposition', or sometimes to 'a person of very great activity, strength, or courage' (Oxford English Dictionary, 2020). As such, the image has similar cognitive mapping conditions to that in Chinese and thus one would expect the translation of the metaphor to retain the ST metaphor without additional glossing. However, this is not the case.

\section{DISCUSSION}

Overall, the data analysis has shown that more translation procedures are employed in the translation of metaphors in President Xi Jinping's speeches than in the translation of metaphors in the political 
texts studied by Zhu and Zeng (2013). Specifically, the procedure 'using the same metaphor combined with sense' is used in addition to the ones found in Zhu and Zeng.

Among the four procedures found, the most frequently used one is the reproduction of the same image in the TL. The use of this procedure reflects similar cognitive mappings between English and Chinese. It is reasonable to conclude that this translation procedure has maintained equivalence in terms of both sense and effect of metaphors. This finding will be useful for metaphor translation teaching when students need guidance.

For the second most frequently used translation procedure, namely, converting metaphor to sense, one would expect it to be used where equivalence, in terms of both the sense and effect of metaphors, is hard to maintain and thus the rhetorical effect would be sacrificed. Nonetheless, the researchers' data analysis showed a mixed and puzzling picture where the procedure is used even when similar metaphors are available in English and thus equivalence could have been fully achieved. Future research surveying translators' thoughts may help resolve this puzzle.

With respect to the third most frequently used translation procedure, i.e., replacing the image in the SL with a standard TL image, the data analysis results are thought-provoking. Firstly, the replacement with a new image, for instance, that of 'journey' with 'race', has imported new elements or new senses, which may be inappropriate in the political context. Secondly, there are cases where on the surface an SL image is replaced and yet conceptually the SL and the TL images belong to the same concept, thus achieving equivalence in both sense and effect. The translation procedure in this manner may have pedagogical significance when translation students are guided on how to apply this procedure to the translation of metaphors.

Regarding the fourth, also the least used, translation procedure, it is hard to generalise its use. One reason is its low frequency of occurrence in the current data set, which is of a limited size. Another reason is that such metaphors reflect similar cognitive mappings in English and Chinese and thus one would think the additional gloss is redundant. Newmark suggests that this occasionally used procedure, as also shown to be the case in the current study, might reveal the translator's lack of confidence in the power and clarity of the metaphor (1980, p.97). This suggestion could be strengthened with empirical evidence from future research. But provided this is the case, the significance of the current finding is that it refreshes the call to train/improve translators' cultural competence.

\section{CONCLUSION}

Drawing upon Lakoff and Johnson's framework of Conceptual Metaphor Theory and Newmark's categorisation of translation procedures for metaphor translation, the current study has found that four translation procedures are used in translating the metaphors in Chinese President Xi Jinping's speeches. These are: (a) reproducing the same image in the TL; (b) replacing the image in the SL with a standard TL image, (c) converting the metaphor to sense and (d) using the same metaphor combined with sense.

The cognitive approach to metaphors employed in the current study has allowed the researchers to investigate the relationships between the choice of a translation procedure and the underlying way of thinking or conceptualising of different cultures. The researchers' detailed data analysis has shown that while the use of procedure (a) mirrors the similarities in conceptualising between the TL and the SL and has achieved equivalence, the use of Procedure (b), (c) and (d) does not present a consistent picture. In particular, the use of Procedure (b) in some cases may be open to controversy as it can import elements that are politically inappropriate, but in other cases, the application of this procedure may speak to metaphor translation pedagogy; Procedure (c) and (d) do not always correlate well with the differences or similarities in cognitive mappings between the two cultures in question, and consequently it is sometimes puzzling why equivalence is at stake. Future research also adopting the cognitive perspective and surveying translators themselves will help find the answer. 
A limitation of the current research is the sample size, as it is a sample instead of the whole data set from the data source, which makes the current findings only indicative. Studies of a larger sample, for example, by using the corpus approach, would help strengthen the research results. Parallel corpora, one for metaphors used by President $\mathrm{Xi}$ and one for the corresponding translations, would contribute to future studies of both Chinese conceptual metaphors and Chinese to English translation of metaphors.

Despite this, the current study will inform translation pedagogy regarding metaphors and will potentially inspire new research studying metaphor translations in political texts. 


\section{REFERENCES}

Aristotle's Rhetoric. (2010). Retrieved from Stanford Encyclopedia of Philosophy: https://plato.stanford.edu/ entries/aristotle-rhetoric/\#8.2

Charteris-Black, J. (2005). Politicians and Rhetoric: The Persuasive Power of Metaphor. Palgrave Macmillan. doi:10.1057/9780230501706

Charteris-Black, J. (2014). Analysing Political Speeches: Rhetoric, Discourse and Metaphor. Palgrave Macmillan. doi:10.1007/978-1-137-36833-1

Chilton, P. (2006). Metaphors in Political Discourse. In K. Brown (Ed.), Encyclopedia of Language \& Linguistics (2nd ed., pp. 63-65). Elsevier Science. doi:10.1016/B0-08-044854-2/00728-8

Chilton, P., \& Schäffner, C. (1997). Discourse and Politics. In T. A. van Dijk (Ed.), Discourse as Social Interaction (pp. 206-230). Sage Publications.

China Daily. (2018). 《习近本谈治国理政》英文翻译团队: 让中国声音被更多人倾听. Accessed from: https://www.thepaper.cn/newsDetail_forward_2203060

Collins COBUILD Dictionary on CD-ROM. (2006). Harper Collins Publishers.

Dobrzyńska, T. (1995). Translating metaphor: Problems of meaning. Journal of Pragmatics, 24(6), 595-604. doi:10.1016/0378-2166(95)00022-K

Gagnon, C. (2010). Political translation. In Y. Gambier \& L. van Doorslaer (Eds.), Handbook of Translation Studies (pp. 252-256). John Benjamins Publishing Company. doi:10.1075/hts.1.pol1

Gibbs, R. W. (Ed.). (2008). Cambridge Handbook of Metaphor and Thought. Cambridge University Press. doi:10.1017/CBO9780511816802

Gibbs, R. W. (2017). Metaphor Wars: Conceptual Metaphors in Human Life. Cambridge University Press. doi: $10.1017 / 9781107762350$

Huang, T. (2014). 关联理论和政治文献的隐喻翻译 [The Relevance Theory and Metaphor Translation in Political Texts]. 海外英语 [Overseas English], (14), 127-128, 130.

Jing-Schmidt, Z., \& Peng, X. (2017). Winds and tigers: Metaphor choice in China's anti-corruption discourse. Lingua Sinica, 3(1), 1-26. doi:10.1186/s40655-016-0017-9

Lakoff, G., \& Johnson, M. (1980). Metaphors We Live By. University of Chicago Press.

Moore, D. S., McCabe, G. P., \& Bruce, C. (2011). Introduction to the Practice of Statistics. WH Freeman.

Newmark, P. (1980). The translation of metaphor. Babel, 26(2), 93-100. doi:10.1075/babel.26.2.05new

Nida, E. A., \& Reyburn, W. D. (1981). Meaning Across Cultures. Orbis Books.

Oxford English Dictionary. (2020). https://www.oed.com/

Schäffner, C. (2004). Metaphor and translation: Some implications of a cognitive approach. Journal of Pragmatics, 36(7), 1253-1269. doi:10.1016/j.pragma.2003.10.012

Shadish, W. R., Cook, T. D., \& Campbell, D. T. (2002). Experimental and quasi-experimental designs for generalized causal inference. Cengage Learning.

Shuttleworth, M. (2014). Translation studies and metaphor studies: Possible paths of interaction between two well-established disciplines. In Tradurre Figure/Translating Figurative Language (pp. 53-65). Centro di Studi Linguistico-Culturali.

Twardzisz, P. (2013). The Language of Interstate Relations. In Search of Personification. Palgrave Macmillan. doi:10.1057/9781137332707

van den Broeck, R. (1981). The Limits of Translatability Exemplified by Metaphor Translation. Poetics Today, 2(4), 73-87. doi:10.2307/1772487 
Weng, J. (2017). 汉语政治文本中的概念隐喻及其翻译策略㗑究 [A Study on Conceptual Metaphor and its Translation Procedures in Political Texts in Chinese]. 海外英语 [Overseas English], 14, 137-138.

现代汉语词典 [Modern Chinese Dictionary]. (2016). ( $7^{\text {th }}$ ed.). The Commercial Press

Xinhua News Agency. (2018). 习近本: 在第十三届全国人民代表大会第一次会议上的讲话 [Speech delivered by Xi Jinping at the first session of the 13th NPC]. Retrieved from: http://www.npc.gov.cn/npc/xinwen/syxw/201803/21/content_2052257.htm

Zhu, X., \& Zeng, G. (2013). 现代汉语政治文本的隐喻模式及其翻译策略:一项基于汉英政治文本平行语 料库的硏究 [Metaphorical Patterns in Modern Chinese Political Discourses and Their Translation Strategies: An Investigation based on Parallel Corpus of Political Discourses]. 解放军外国语学院学报 [Journal of PLA University of Foreign Languages], 36(5), 82-86, 128.

\section{ENDNOTE}

As has been accepted practice in cognitive linguistics, 'upper case is used to show the abstract thoughts (or propositions) underlying metaphors that are usually known as conceptual metaphors' (Charteris-Black, 2005, p. xii).

Yiqing Liu is a translator and interpreter at China Foreign Languages Publishing Administration, China. She has been a freelance translator and interpreter for the UN family of organizations, including UNDP, UNEP, and WIPO. She received her MSc degree in Specialised Translation with Interpreting from University College London, UK and her MA degree in Simultaneous Interpreting from Beijing Foreign Studies University, China.

Caiwen Wang is a Senior Lecturer in Translation and Interpreting Studies in the School of Humanities of the University of Westminster, UK, having taught both translation and interpreting at the theoretical and practical level. Her research interests are translation and interpreting studies and applied linguistics in general, and she has published in all the three areas. 